\author{
Waldemar Kowalski \\ https://orcid.org/oooo-0003-1692-338X \\ Uniwersytet Jana Kochanowskiego w Kielcach
}

\title{
Niemieccy kupcy i czarownica w Krakowie w 1642 r.
}

25 października 1642 r. krakowianin Adam Fister zdał relację miejscowemu wójtowi o magicznych rytuałach odprawianych na prośbę lubeckiego kupca Kaspra Bekmana przez czarownicę w ogrodzie szpitalnym za murami miejskimi, nieopodal Bramy Floriańskiej. Wzmiankowany w źródle szpital-przytułek sąsiadował z cmentarzem, którego groby odkryto w 1837 r. Połączono je wtedy bezpodstawnie z braćmi polskimi, a współczesnym świadectwem tej fałszywej tradycji jest ul. Ariańska. Faktycznie szpital i cmentarz należały do miejscowej gminy luterańskiej, jej członkami byli zaś zapewne wymienieni w źródle krakowscy kupcy.

On 25 October 1642, Adam Fister, a Cracow merchant, reported to the local justice that the Lübeck tradesman Casper Bekman had recurred to magical practices with the help of the witch he visited at the Spital Garden, behind the city walls, near St Florian's Gate. Next to the Spital, serving as an almshouse, there was a cemetery with the graves discovered in 1837 . They were groundlessly connected with the Polish Brethren, and this false interpretation has its continuation today in the name of Arian St., downtown Cracow. In fact, the hospital and the graveyard belonged to the local Lutheran congregation, and the Cracow merchants whose opinions Fister recalled at the court were its members.

Słowa kluczowe: czary, kupcy, ewangelicy, sąd wójtowski, wczesnonowożytny Kraków, przytułek

Ke yw o r d s: witchcraft, merchants, Evangelicals, city justice, early modern Cracow, almshouse 
Wczesnonowożytnych kupców poznajemy zwykle, gdy zawierają lub rozliczają umowy handlowe, regulują wzajemne zobowiązania, w tym testamentowe, lub opłacają podatki. Sporadycznie przybliżyć można zaangażowanie nielicznych $\mathrm{z}$ nich na rzecz współwyznawców i duszpasterza, a to również na ogół z perspektywy zapisów finansowych, czynionych darowizn lub niewywiązywania się z nich. Przekonania religijne, indywidualne postawy względem nakazów prawa Bożego $\mathrm{z}$ trudem poddają się ocenom czynionym na podstawie nie tylko akt miejskich, ale także proweniencji kościelnej.

$\mathrm{Z}$ tych powodów na przedstawienie zasługuje krótki, lecz o ponadprzeciętnych walorach poznawczych wpis do akt wójta krakowskiego dokonany w 1642 r. Choć skąpo, to jednak oświetla on stosunek niektórych miejscowych kupców oraz ich gości do czarów i korzyści płynących z ich uprawiania. Wartość tego przekazu wynika nadto z okoliczności, w których został on sporządzony. Nie jest to bowiem dokumentacja procesu o czary, a świadectwo moralnej oceny takich praktyk, poczynione dla podkreślenia ich naganności. Taki ostrożny wniosek wysnuć można bowiem $\mathrm{z}$ tego lapidarnego zapisu.

Zagadnienie czarów oraz związanych z nimi procesów sądowych ma już sporą literaturę, także w odniesieniu do ziem polskich oraz krajów z nimi sąsiadujących ${ }^{1}$. Późnośredniowieczny i wczesnonowożytny Kraków zapewne nie wyróżniał się szczególnie pod tym względem pośród innych ważniejszych miast Królestwa. $\mathrm{Na}$ podstawie nielicznych dotychczasowych opracowań przybliżających oskarżenia o czary w stolicy oraz jej okolicach dość wyraźnie rysuje się przede wszystkim występowanie takich praktyk we wszystkich stuleciach - od XV po XVIII. U schyłku wieków średnich zwalczali je m.in. tak wybitni profesorowie krakowskiej wszechnicy i kaznodzieje jak Stanisław ze Skarbimierza (zm. 1431) czy jego uczeń, Łukasz z Wielkiego Koźmina (zm. 1412)².

1 Z ważniejszych i nowszych opracowań zob. J. Adamczyk, Czary i magia w praktyce sąów kościelnych na ziemiach polskich w późnym średniowieczu (XV-potowa XVI wieku), w: Karolinscy pokutnicy i polskie średniowieczne czarownice. Konfrontacja doktryny chrześcijańskiej z życiem spoteczeństwa średniowiecznego, red. M. Koczerska, Warszawa 2007 (Fasciculi Historici Novi, t. 7), s. 91-260; J. Wijaczka, Procesy o czary w Prusach Ksiażęcych (Brandenburskich) w XVI-XVIII wieku, Torun 2007; idem, Magia i czary. Polowanie na czarownice i czarowników w Prusach Ksiązęcych w czasach wczesnonowożytnych, Torun 2008; M. Pilaszek, Procesy o czary w Polsce $w$ wiekach $X V$-XVIII, Kraków 2008 oraz istotne uwagi do tej pracy J. Wijaczki (rec. w: „Kwartalnik Historyczny”, 116, 2009, s. 113-126).

2 Szerzej zob. M. Kowalczykówna, Wróżby, czary $i$ zabobony w średniowiecznych rękopisach Biblioteki Jagiellońskiej, „Biuletyn Biblioteki Jagiellońskiej”, 29, 1979, 
Nieelitarny i akceptowany przez Kościół „światopogląd astrologiczny” umacniał jednak wiarę w skuteczność ponadnaturalnej ingerencji w przyszłe sprawy osób obdarzonych magiczną wiedzą ${ }^{3}$. Podczas gdy prognozy astrologiczne zyskały sankcję uczoności, lecz dostępne były jedynie relatywnie lepiej sytuowanym, ogół zwracał się z pytaniami o przyszłość i możliwość kierowania ludzkimi losami do oficjalnie potępianych czarownic. Trudno orzec, w jakim stopniu reprezentatywna jest znana dziś raczej skromna liczba takich oskarżeń wysuniętych we wczesnonowożytnym Krakowie, z których większość sformutowano w pierwszej połowie XVIII w. ${ }^{4}$

O tym, że magiczne praktyki były domeną tzw. bab, do których nietrudno było trafić tak na wsi, jak w mieście, informują m.in. wzmiankowani już średniowieczni autorzy ${ }^{5}$. O kobietach tych pisał w 1600 r. Sebastian Klonowic: „Także też baby rzkomo mendicatum chodzą / tak uczciwe mężatki i panienki zwodzą / czarują i lekują, wróżą, wieści noszą/ stadło łączą, a w rzeczy o jałmużnę proszą"6. Nie ma podstaw, aby nie wierzyć słowom nieujawnionego autora słynnego traktatu Czarownica powotana ${ }^{7}$, który informuje, że „temi czasy nasza Wielkopolska niezwyczajnie zagęściła się [- - czarownicami, lubo

s. 5-18; ostatnio W. Brojer, Między pastwiskiem i akademia. Stanistawa ze Skarbimierza kazanie "o zabobonach”?, w: Ambona. Teksty o kulturze średniowiecza ofiarowane Stanistawowi Bylinie, red. K. Bracha, W. Brojer, Warszawa 2016, s. $147-191$.

3 Szerzej zob. W. Brojer, op. cit., s. 190; S. Konarska-Zimnicka, „Wenus pania roku, Mars towarzyszem..." Astrologia w Krakowie XV i poczatku XVI wieku, Kielce 2018.

4 J. Kracik, M. Rożek, Hultaje, złoczyńcy, wszetecznice w dawnym Krakowie. O marginesie spotecznym XVI-XVIII w., Kraków 1986, s. 110-115. Odpowiada to chronologii występowania opisywanego zjawiska w szerszej skali, o czym m.in. J. Tazbir, Procesy o czary, OiRwP, 23, 1978, s. 152, 175.

5 M. Kowalczykówna, op. cit., s. 6. Informacji takich dostarczają także akta konsystorskie; zob. S. Bylina, Magia, czary i kultura ludowa w Polsce XV i XVI w., OiRwP, 35, 1990, s. 43; L. Zygner, Kobieta-czarownica $w$ świetle ksiag konsystorskich z XV i początku XVI w., w: Kobieta i rodzina $w$ średniowieczu $i$ na progu czasów nowożytnych, red. Z. H. Nowak, A. Radzimiński, Toruń 1998, s. 91-101; J. Adamczyk, op. cit., passim.

6 S. Klonowic, Worek Judaszów, to jest zte nabycie majętności, Kraków: Sebastian Sternacki, 1603, BN, sygn. XVII.3.1419, k. nlb.; zob. A. Kawecka-Gryczowa, Arianskie oficyny wydawnicze Rodeckiego i Sternackiego. Dzieje i bibliografia, Wroclaw 1974, s. 225-226.

7 Identyfikowany jest on jako osoba bliska poznańskiemu drukarzowi Wojciechowi Regulusowi, którego typografię opuścił wspominany tu druk; J. Sójka, Regulus Wojciech, PSB, 30, 1987, s. 749; W. Wyporska, Witchcraft in Early Modern Poland, 1500-1800, Basingstoke-New York 2013, s. 174. 
prawdziwemi, lubo mniemanemi" ". Nie widać powodów, dla których sytuacja ta miałaby wyglądać zdecydowanie inaczej w Małopolsce.

Kobiety te zaliczane były do tzw. ludzi luźnych i bywało, że spotykały się z takim jak oni potępieniem ${ }^{9}$. W publikowanym tu źródle zwraca uwagę wysokie, dwustuzłotowe honorarium zainkasowane przez „czarownicę”. Kobiety parające się tym zawodem zadowalały się raczej niewielkimi sumami, choć nie było to regułą ${ }^{10}$. Krakowski przekaz sugeruje, że nie bez znaczenia mogła być tu pozycja zawodowa i majątkowa petenta. Mimo jednak powszechności tej profesji oraz, jak widzimy, potencjalnie wysokich korzyści płynących z jej uprawiania, czarownice nie były postrzegane przez autorów szesnastowiecznych taryf pogłównego jako osobna kategoria społeczno-zawodowa ${ }^{11}$.

W powszechnym mniemaniu szeroki był katalog spraw, w których kobiety te skutecznie interweniowały ${ }^{12}$. Równie rozległy był krąg osób korzystających z ich usług i uciekających się do magii ${ }^{13}$. Nie zaskakuje więc obecność na kartach stołecznych ksiąg wójtowskich kupców

8 Czarownica powotana abo krótka nauka i przestroga z strony czarownic, Poznań 1639, BCz, sygn. 40554I, k. Arec. W owym czasie w luterańskiej Danii czarownice „prawdziwe” to te, których działania nakierowane były na wyrządzenie szkody bliźnim; L. Nyholm Kallestrup, Knowing Satan from God. Demonic Possession, Witchcraft, and the Lutheran Orthodox Church in Early Modern Denmark, „Magic, Ritual, and Witchcraft”, 6, 2011, s. 167.

9 Zob. U. Augustyniak, Koncepcje narodu i spoteczeństwa w literaturze plebejskiej od końca XVI do końca XVII wieku, Warszawa 1989, s. 112-114. Czarownic pośród „kobiet powłócznych” nie wymienia B. Baranowski; idem, Ludzie gościńca w XVII-XVIII w., Łódź 1986, s. 206-228.

10 Reprezentatywne w szerszym zakresie są tu ustalenia J. Wijaczki (idem, Magia i czary, s. 68-69); por. B. P. Levack, Polowanie na czarownice w Europie wczesnonowożytnej, tł. E. Rutkowski, z dodatkiem Katalogu magii Mnicha Rudolfa zabytku z XIII w. w tł. [z łac.] E. Karwota, Wrocław 1991, s. 159, według którego, choć „często żyły na granicy minimum egzystencji”, to jednak „niekoniecznie należały do najuboższych warstw”. Według J. Adamczyk (op. cit., s. 176) znachorstwo i magia mogły przynosić spore dochody.

11 Tak wynika z badań A. Wyczańskiego; idem, Uwarstwienie społeczne $w$ Polsce XVI wieku. Studia, Wrocław 1977, s. 220-221.

12 Zob. m.in. S. Bylina, op. cit., s. 45-51; J. Wijaczka, Procesy o czary, s. 234-294; idem, Magia i czary, s. 36-109.

13 Zdaje się, że stosunkowo rzadko uwikłani byli w wynikające z tego procesy polscy duchowni - także przed początkiem XVII stulecia, od kiedy to skuteczniejsza staje się egzekucja kościelnej dyscypliny. Świadczy o tym katalog zarzucanych im wykroczeń; zob. N. Nowakowska, Church, State and Dynasty in Renaissance Poland. The Career of Cardinal Fryderyk Jagiellon (1468-1503), Aldershot-Burlington (VT) 2007 (Catholic Christendom, 1300-1700), s. 81-87; S. Bylina, op. cit., s. 42-43; J. Adamczyk, op. cit., s. 184. 
z miast, w których językiem podstawowym był niemiecki, aczkolwiek Lubeka i Wiedeń nie należały do ośrodków, z którymi Kraków utrzymywał ściślejsze relacje handlowe. Żywe takie kontakty utrzymywano natomiast z Gdańskiem ${ }^{14}$. Znajomość wymienionych w źródle kupców z Gdańska i Lubeki jest, wolno sądzić, naturalną konsekwencją trwałych więzów gospodarczych łączących miasta rejonu Bałtyku ${ }^{15}$. Kupcy ci, jak również ich wiedeński towarzysz, pozostają bliżej nieznani ${ }^{16}$. Nasza wiedza o wymienionych w źródle krakowianach ogranicza się do cukiernika Izaaka Maierhovera (jak w omawianym źródle lub Mayerhöfera) i jego drugiej żony Zuzanny. Znani są oni skądinąd jako członkowie (audytorzy) miejscowego zboru ewangelicko-reformowanego, wspomniany zaś cukiernik często występuje pośród starszych swej gminy wyznaniowej ${ }^{17}$. Jest wysoce prawdopodobne, że inni wymienieni w zeznaniu krakowianie: Jan Brauer, Maciej Erfort, Adam Fister oraz Piotr Rotenstein to ewangelicy augsburscy. O kongregacji tej nie wiemy nic ponad to, że lokalnie pozostawała w konfesyjnej bliskości z wyznawcami nauk szwajcarskich teologów. Porozumienie, które w 1636 r. krakowscy luteranie zawarli z miejscowymi kalwinistami, uprawniało ich do korzystania z kaplicy tych ostatnich. Osobno jednak odprawiali nabożeństwa i przystępowali do sakramentu Stołu Pańskiego. W przeciwieństwie do ewangelików reformowanych albo nie spisywali komunikujących, albo spisy takie nie zachowały $\operatorname{się}^{18}$.

14 Stwierdzam to na podstawie ustaleń J. Wijaczki; idem, Handel zagraniczny Krakowa w potowie XVII wieku, Kraków 2002, s. 57, 81-88, 104.

15 O kontaktach gospodarczych i kulturalnych tych miast m.in. A. Cowan, Cultural Traffic in Lübeck and Danzig in the Sixteenth and Seventeenth Centuries, "Scandinavian Journal of History", 28, 2003, s. 175-185; por. K. Stadin, Seventeenth Century Baltic Merchants, w: Baltic Towns and Their Inhabitants. Aspects on Early Modern Towns in the Baltic Area, red. K. Stadin, Huddinge 2003, s. 56-73, gdzie obszerna literatura przedmiotu.

16 Wiadomo jednak, że kupcy o nazwisku Beckmann zamieszkiwali w owym czasie Lubekę; F. Siewert, Die Lübecker Rigafahrer-Compagnie im 16. und 17. Jahrhundert, Berlin 1896, s. 79-80.

17 Kronika zboru ewangelickiego krakowskiego przez X. Wojciecha Wegierskiego, oprac. M. Pawelec, Kraków 2007, s. 125, passim. Zuzanna wymieniona została wśród audytorów w 1637 r.; Archiwum Parafii Ewangelicko-Augsburskiej w Krakowie, Księga wtóra, br. sygn., k. 8rec.

18 Archiwum Parafii Ewangelicko-Augsburskiej w Krakowie, Księga wtóra, br. sygn., k. 45rec.; Kronika zboru ewangelickiego, s. 112; zob. też J. Wijaczka, Luteranie $w$ Koronie od 1517 do 1795 r., w: Kościoty luterańskie na ziemiach polskich $(X V I-X X$ w.), t. 1: W czasach Rzeczypospolitej Obojga Narodów, red. J. Kłaczkow, Toruń 2012, s. 47. 
Luteranami byli też zapewne skonfliktowani kupcy z Gdańska i Lubeki. Jak wiadomo, więzy wyznaniowe miały wówczas fundamentalne znaczenie dla budowania szerszych relacji - handlowych i towarzyskich ${ }^{19}$.

Kazimierz Bem zauważył ostatnio, że ewangelicy reformowani w Rzeczypospolitej wykazywali godną uwagi obojętność względem czarów i magii. Nie znaczy to jednak, że odrzucali przydatność tak prokurowanych ponadnaturalnych interwencji ${ }^{20}$. Wiara ta łączyła bowiem ponad podziałami wyznaniowymi. W luterańskim Gdańsku, skąd pochodził wnoszący skargę Jan Minen, przestępstwa takie były nieliczne, ale surowo karane ${ }^{21}$. Choć teolodzy luterańscy byli zwolennikami bezwzględnego tępienia czarownic, problem korzystania $\mathrm{z}$ ich pomocy starali się rozwiązywać, przede wszystkim akcentując konieczność wzmacniania dyscypliny wiernych oraz poprawnego pojmowania przez nich zasad wiary ${ }^{22}$. Wzmiankowany w zeznaniu ogród szpitalny za Bramą Floriańską, w pobliżu miejskiej Strzelnicy, bez wątpienia identyfikować wypada z miejscem znanym krakowianom do początku XIX stulecia jako Ogród Luterski. Odkryte tam w 1837 r. pochówki nazwano wtedy „grobami ariańskimi” - bez jakichkolwiek ku temu podstaw źródłowych ${ }^{23}$. W świetle analizowanego tu zapisu

19 Zob. K. Friedrich, Cives Cracoviae: Bürgertum im frühneuzeitlichen Krakau zwischen Stadtpatriotismus und nationaler Pluralität, w: Krakau, Prag und Wien. Funktionen von Metropolen im frühmodernen Staat, hrsg. M. Dmitrieva, K. Lambrecht, Stuttgart 2000, s. 143-162; por. J. Colson, A. van Steensel, Cities and Solidarities. Urban Communities in Medieval and Early Modern Europe, w: Cities and Solidarities. Urban Communities in Pre-Modern Europe, ed. J. Colson, A. van Steensel, London-New York 2017, s. 4-7.

20 K. Bem, "The Devil Went Down to Oksa" - Witchcraft, Calvinist Piety in Midseventeenth Century Private Town in Poland, artykuł w druku. Autorowi dziękuję za jego udostępnienie.

21 D. Kaczor, Przestępczość kryminalna i wymiar sprawiedliwości w Gdańsku w XVI-XVIII wieku, Gdańsk 2005 (Gdańskie Studia z Dziejów Nowożytnych, t. 2), s. $160-165$.

22 Szerzej o tym zob. L. Nyholm Kallestrup, op. cit., s. 165.

23 Utrwalona więc do dziś w nazwie ul. Ariańskiej późniejsza dziewiętnastowieczna tradycja placu Ariańskiego jest całkowicie błędna; J. Laberschek, Rozwój przestrzenny krakowskiego zespotu osadniczego extra muros XIII-XVIII w., w: Kraków. Nowe studia nad rozwojem miasta, red. J. Wyrozumski, Kraków 2007 (Biblioteka Krakowska, t. 150), s. 344 oraz tamże mapa 1 pt. Sieć wodna i zabudowa aglomeracji krakowskiej w XVI w., oprac. J. Laberschek; W. Komorowski, Protestanckie miejsca $w$ Krakowie $w$ XVI wieku: zbory, domy, cmentarze, w: Reformacja $w$ Krakowie (XVI-XVII wiek). Materiaty z sesji naukowej 6 maja 2017 roku, red. Z. Noga, Kraków 2018, s. 163-164. 
zasadne jest natomiast interpretowanie tych grobów jako pozostałości cmentarza krakowskich ewangelików augsburskich, którzy - jak możemy się domyślać - posiadali tam też swój przytułek. „Baba” była zapewne jego podopieczną, niemieccy kupcy zaś tymczasowymi lokatorami ${ }^{24}$.

Nie ulega wątpliwości, że była ona osobą znaną krakowskiemu plebsowi, a honorarium, które otrzymała, pozwala sądzić, że przekonanie o jej skuteczności nie było jednostkowe. Według wszelkiego prawdopodobieństwa przedstawione wójtowi okoliczności korzystania z jej usług nie miały konsekwencji prawnych. Dalsza kwerenda w księgach tego urzędu przyniosła wynik negatywny. Sprawa nie trafiła do sądu ordynariusza miejsca lub jego oficjała ${ }^{25}$. Oskarżenia, które - jak czytamy - Kasper Bekman miał wnieść do krakowskiego grodu, również nie udało się odnaleźćc ${ }^{26}$.

Szukając odpowiedzi na pytanie, dlaczego sprawie wizyt u czarownicy nie nadano dalszego biegu, wskazać należy następujące okoliczności. Bekman zrezygnował z korzystania z jej usług. Zwyciężyła perswazja oparta na argumencie dowodnie powtarzanym w Krakowie przynajmniej od schyłku XIV w., że czary obrażają Boga. Opinię tę podzielały intelektualne elity zachodniej i środkowej Europy, a przekonanie takie upowszechniało się do schyłku lat trzydziestych XVII w. ${ }^{27}$ Krakowski wójt przychylił się, jak widzimy, do ogłoszonej trzy lata wcześniej argumentacji autora Czarownicy powołanej. Według niego na sąd i karę zasługują tylko niektóre kobiety

${ }^{24}$ O szpitalu tym nie wspomina L. Wachholz, O szpitalach innowierców w Krakowie. Szkic historyczny, „Archiwum Historii i Filozofii Medycyny”, 2, 1925, s. 173-176. Nic nie wnosi tu też A. Madej-Anderson, Lutherans in Cracow Contesting the Sacred Topography, w: Lutheran Churches in Early Modern Europe, ed. A. Spicer, Farnham-Burlington (VT) 2012, s. 377-402.

25 Co stwierdzamy na podstawie kwerendy w Archiwum Kurii Metropolitalnej w Krakowie (przejrzano księgi wpisów za lata 1641-1643: sygn. AAdm 14, AEp 50, Aoff 129, 130). Oceniając kompetencje w sądzeniu takich spraw sądów kościelnych i świeckich, M. Mikołajczyk (idem, Proces kryminalny $w$ miastach Matopolski XVI-XVIII wieku, Katowice 2013, s. 62-63) mówi o „konkurencji przepisów”.

26 ANK, Castrensia Cracoviensia Inscriptiones, sygn. 253-256.

27 Szerzej zob. E. Bever, Witchcraft Prosecutions and the Decline of Magic, "The Journal of Interdisciplinary History”, 40, 2009, s. 263-293. Autor zastrzega jednak, że coraz powszechniejsza taka świadomość nie oznaczała całkowitej negacji problemu czarów i czarownic nawet w kręgach elitarnych. Miała też regionalnie zróżnicowany wpływ na wszczynanie procesów sądowych. 
uprawiające magię, a mianowicie te, które czynią to z intencją zaszkodzenia bliźnim, nie zaś „zabobonice”. Zabobony bowiem „pospolicie nie podpadają rozsądkowi i karaniu prawa świeckiego" 28 . Z tej perspektywy szkodliwość konsultacji krakowskiej „baby czarownicy” była relatywnie niewielka, gdyż nie miały one konsekwencji kryminalnych. Joanna Adamczyk słusznie podkreśla, że w takich sytuacjach złem była chęć osiągnięcia korzyści poza prawem Boskim ${ }^{29}$. Przedstawiany tu przypadek potwierdza też dotychczasowe obserwacje, że tylko stosunkowo niewielka liczba osób parających się magią czy wróżbiarstwem trafiała przed oblicze sądu - kościelnego czy świeckiego ${ }^{30}$. Zdaniem Janusza Tazbira „procesy o czary były [- $]$ u nas społeczno-kryminalnym problemem niższych sfer" ${ }^{\prime \prime}$, do których wymienieni w źródle kupcy raczej się nie zaliczali.

Rękopis, w którym zamieszczono analizowane tu zeznanie, to księga zawierająca wpisy urzędu i sądu wójta oraz sądu wójtowsko-ławniczego w Krakowie. Podobnie jak inne księgi tej serii akt miasta Krakowa, informuje ona o rozstrzyganych tam spornych i niespornych sprawach mieszczan, przede wszystkim cywilnych. Interesującą nas księgę założono przed 2 stycznia 1577 r. i kontynuowano do 25 maja tego roku. Ponieważ pozostawiono wtedy wiele pustych kart, wolne miejsca woluminu wykorzystano, zapisując je między 1624 a $1651 \mathrm{r}^{32}$ Współcześnie oprawiona księga jest dziełem wielu rąk. Przedstawiona tu narracja utrwalona została pismem czytelnym, typową dla epoki lekko kursywną kancelareską ${ }^{33}$. Stan zachowania księgi jest dobry.

28 Czarownica powotana, k. Aii rec.-5.

29 J. Adamczyk, op. cit., s. 116-117. Dodatkowych argumentów za tą tezą dostarczają podobne zdarzenia, jednak z aspektem kryminalnym, o czym szerzej K. Pilaszek, op. cit., s. 357-358. Podobnie stanowiło średniowieczne prawo Jutlandii, obowiązujące do 1617 r.; L. Nyholm Kallestrup, op. cit., s. 166.

30 S. Bylina, op. cit., s. 42-43; L. Zygner, op. cit., s. 98, 101; J. Adamczyk, op. cit., s. 175-176, 181, 208-209, 251.

31 J. Tazbir, op. cit., s. 167.

32 Katalog Archiwum Aktów Dawnych Miasta Krakowa, t. 2, Kraków, rękopisy nr 1-3568, [red. S. Krzyżanowski], Kraków 1915, s. xiii-xiv, 36-37, sygn. 193; zob. też Z. Noga, Urzędnicy miejscy Krakowa, cz. 2: 1500-1794, Kraków 2008 (Spisy urzędników miejskich z obszaru dawnej Rzeczypospolitej, Śląska i Pomorza Zachodniego, t. 3: Małopolska, z. 1: Kraków), s. xxxi-xxxiii; M. Mikołajczyk, op. cit., s. 26-28.

33 Szerzej zob. J. Słowiński, Rozwój pisma tacińskiego w Polsce XVI-XVIII wieku, Lublin 1992, s. 104-116. 
Taką podstawę wydania przygotowano zgodnie z ogólnie przyjętymi zasadami edytorskimi ${ }^{34}$. Występujące $\mathrm{w}$ tekście konwencjonalne skróty rozwijano bez zaznaczania tego. Nadto nieznacznie zmodyfikowano interpunkcję oryginału.

\section{Edycja}

ANK, Akta miasta Krakowa, Advocatialia Cracoviensia. Codex actorum scabinalium et advocatialium Cracoviensium [- ], sygn. 193

[s. 343] Actum coram officio advocatiali Cracoviensi sabbato pridie festum s. Ursulæ et 11000 virginum proximo, die 25 Octobris anno Domini 1642

Ad quod quidem officium adcitatus per providum Stanislaum Brzeszkowic, bedellum judicii scabinalis Cracoviensis juratum existens, famatus Adamus Fister, civis ac mercator Cracoviensis, ex instantia nobilis Joannis Minen, patricii Gedanensis, ad perhibendum veritatis in infra expressis, testimoniam personaliterque comparens ac diligenter examinatus, prævio corporali juramento, de forma juris, videlicet, per erectionem duorum versus cœlum manus dextræ digitorum, in vim fidelis testimonii sui recognovit in hæc sequentia verba.

Roku teraźniejszego tysiącznego sześćsetnego czterdziestego wtórego, in mense Februario, gdym był u pana Matiasa Erforta, stolarza i mieszczanina krakowskiego, w mieszkaniu jego na Sławkowskiej ulicy, słyszałem to, tak od niego samego, jako tyż i od pana Piotra Rotensteina, mieszczanina także krakowskiego, i od pana Daniela Fransa, kupca wiedeńskiego, który mi to w domu u mnie będąc co i pan Matias Erford powiadali, że słyszeli z ust pana Jana Brauera, obywatela tutecznego krakowskiego, że pan Kasper Bekman, kupiec z Lubeka, pobrawszy rzeczy, to jest pościel, szaty i insze rzeczy ruchome pana Jana Minena, Gdańszczanina, a inducenta teraźniejszego, od wzwyż namienionego Matiasa Erforta, czarował z babą czarownicą w ogrodzie szpitalnym, idąc na Strzelnicę, za bramą Floriańską leżącą, przerzeczonego Jana Minena, Gdańszczanina, które czarowanie kosztowało pomienionego Kaspra Bekmana złotych dwieście. A to dlatego, aby się tu, gdyż był odjachał, nazad powrócił, gdyż tu miał w grodzie

34 Instrukcja wydawnicza dla źródet historycznych: od XVI do potowy XIX wieku, red. K. Lepszy, Wrocław 1953. 
krakowskim sprawę z tym to Kasprem Bekmanem. I to tyż przede mną powiadali, że pan Jan Brauer, zostawszy w ogrodzie wyżej mianowanym pomienionego Kaspra Bekmana z babą czaro[s. 344]wnicą czary czyniącego, mówił mu i upominał go, aby tych czarów poniechał, rozważając, gdyż to jest przeciwko Bogu i bliźniemu. Na którą persuazyją jego nie kazał więcej namieniony Bekman takowych czarów czynić.

Ja potym, chcąc się dowiedzieć pewności mów przerzeczonych, chodziłem do ogrodu wzwyż namienionego. A tam gospodarza obaczywszy, pytałem go o wyżej namienionych rzeczach, których mi tak powiedział, że pan Bekman pomieniony mieszkał w tym ogrodzie z drugim swym towarzyszem, Niemcem mało nie cały tydzień, u których pan Jan Braur na każdy dzień bywał. Jam go pytał, coby tu pomieniony pan Bekman z towarzyszem swym czynił. $\mathrm{Na}$ co mi odpowiedział, że dziwuje się temu, coby tu za zabawy swe mieli, gdyż na górze, lubo to zimna były, to jest na sauli ${ }^{35}$ mieszkali i tam zawsze we dnie pisali.

To przydając ten to gospodarz, że tam u tego pana Bekmana i z towarzyszem jego bywały dwie białegłowy, to jest pana Izaaka Maierhovera, cukiernika i mieszczanina krakowskiego małżonka, a drugiej nie znam. To na koniec przydając, że pomieniony pan Bekman i z towarzyszem swym kryjmo wyjachali stamtąd, nie dawszy pomienionemu gospodarzowi, tylko złotych półtora.

To tak com słyszał, przysięgą potwierdzam. Quam quidem prædicti testis depositionem, juramento roboratam, officium prædictum advocatiale ad acta sua suscepit, ac prænotato inducenti in authentica extradidit forma.

\section{Bibliografia}

\section{Źródła archiwalne}

Archiwum Kurii Metropolitalnej w Krakowie

Acta Administratorialia, sygn. AAdm 14

Acta Episcopalia, sygn. AEp 50

Acta officialia, sygn. Aoff 129, 130

35 Od niemieckiego rzeczownika Saal; tu - jak wynika z tekstu źródła - nieopalana sala na piętrze lub strychu szpitala; zob. Z. Góralski, Szpitale na Lubelszczyźnie w okresie przedrozbiorowym, Warszawa-Łódź 1982, s. 37-39; J. A. Chrościcki, O budynkach szpitali, przytutków i alumnatów, w: Charitas. Mitosierdzie i opieka spoteczna $w$ ideologii, normach postepowania i praktyce spoteczności wyznaniowych w Rzeczypospolitej XVI-XVIII wieku, red. U. Augustyniak, A. Karpiński, Warszawa 1999, s. 195-200. 
Archiwum Narodowe w Krakowie

Akta miasta Krakowa, Advocatialia Cracoviensia, sygn. 193

Castrensia Cracoviensia Inscriptiones, sygn. 253-256

Archiwum Parafii Ewangelicko-Augsburskiej w Krakowie

Księga wtóra, br. sygn.

\section{Źródła drukowane}

Czarownica powotana abo krótka nauka i przestroga z strony czarownic, Poznań: [Wojciech Regulus], 1639, BCz, sygn. 40554I

Klonowic S., Worek Judaszów, to jest złe nabycie majętności, Kraków: Sebastian Sternacki, 1603, BN, sygn. XVII.3.1419

Kronika zboru ewangelickiego krakowskiego przez X. Wojciecha Węierskiego, oprac. M. Pawelec, Kraków 2007

\section{Opracowania}

Adamczyk J., Czary i magia w praktyce sadów kościelnych na ziemiach polskich w późnym średniowieczu (XV-połowa XVI wieku), w: Karolinscy pokutnicy i polskie średniowieczne czarownice. Konfrontacja doktryny chrześcijańskiej z życiem spoteczeństwa średniowiecznego, red. M. Koczerska, Warszawa 2007 (Fasciculi Historici Novi, t. 7), s. 91-260

Augustyniak U., Koncepcje narodu i spoteczeństwa $w$ literaturze plebejskiej od końca XVI do końca XVII wieku, Warszawa 1989

Baranowski B., Ludzie gościnca w XVII-XVIII w., Łódź 1986

Bem K., "The Devil Went Down to Oksa" - Witchcraft, Calvinist Piety in Mid-Seventeenth Century Private Town in Poland, artykuł w druku

Bever E., Witchcraft Prosecutions and the Decline of Magic, "The Journal of Interdisciplinary History", 40, 2009, s. 263-293

Brojer W., Między pastwiskiem i akademia. Stanistawa ze Skarbimierza kazanie „o zabobonach”?, w: Ambona. Teksty o kulturze średniowiecza ofiarowane Stanistawowi Bylinie, red. K. Bracha, W. Brojer, Warszawa 2016, s. 147-191

Bylina S., Magia, czary i kultura ludowa w Polsce XV i XVI w., OiRwP, 35, 1990, s. 39-52

Chrościcki J. A., O budynkach szpitali, przytutków i alumnatów, w: Charitas. Mitosierdzie i opieka spoteczna $w$ ideologii, normach postępowania i praktyce spoteczności wyznaniowych w Rzeczypospolitej XVI-XVIII wieku, red. U. Augustyniak, A. Karpiński, Warszawa 1999, s. 195-200

Colson J., Steensel A. van, Cities and Solidarities. Urban Communities in Medieval and Early Modern Europe, w: Cities and Solidarities. Urban Communities in Pre-Modern Europe, ed. J. Colson, A. van Steensel, London-New York 2017, s. 1-24

Cowan A., Cultural Traffic in Lübeck and Danzig in the Sixteenth and Seventeenth Centuries, „Scandinavian Journal of History”, 28, 2003, s. 175-185 
Friedrich K., Cives Cracoviae: Bürgertum im frühneuzeitlichen Krakau zwischen Stadtpatriotismus und nationaler Pluralität, w: Krakau, Prag und Wien. Funktionen von Metropolen im frühmodernen Staat, hrsg. M. Dmitrieva, K. Lambrecht, Stuttgart 2000, s. 143-162

Góralski Z., Szpitale na Lubelszczyźnie w okresie przedrozbiorowym, Warszawa-Łódź 1982

Instrukcja wydawnicza dla źródet historycznych: od XVI do potowy XIX wieku, red. K. Lepszy, Wrocław 1953

Kaczor D., Przestępczośc kryminalna i wymiar sprawiedliwości w Gdańsku w XVI-XVIII wieku, Gdańsk 2005 (Gdańskie Studia z Dziejów Nowożytnych, t. 2)

Katalog Archiwum Aktów Dawnych Miasta Krakowa, t. 2, Kraków, rękopisy nr 1-3568, [red. S. Krzyżanowski], Kraków 1915

Komorowski W., Protestanckie miejsca w Krakowie w XVI wieku: zbory, domy, cmentarze, w: Reformacja $w$ Krakowie (XVI-XVII wiek). Materiaty z sesji naukowej 6 maja 2017 roku, red. Z. Noga, Kraków 2018, s. 139-164

Konarska-Zimnicka S., „Wenus pania roku, Mars towarzyszem... " Astrologia w Krakowie XV i poczatku XVI wieku, Kielce 2018

Kowalczykówna M., Wróżby, czary i zabobony w średniowiecznych rękopisach Biblioteki Jagiellońskiej, „Biuletyn Biblioteki Jagiellońskiej”, 29, 1979, s. $5-18$

Kracik J., Rożek M., Hultaje, ztoczyńcy, wszetecznice w dawnym Krakowie. O marginesie spotecznym XVI-XVIII w., Kraków 1986

Laberschek J., Rozwój przestrzenny krakowskiego zespotu osadniczego extra muros XIII-XVIII w., w: Kraków. Nowe studia nad rozwojem miasta, red. J. Wyrozumski, Kraków 2007 (Biblioteka Krakowska, t. 150), s. 297-354

Levack B. P., Polowanie na czarownice $w$ Europie wczesnonowożytnej, tł. E. Rutkowski, z dodatkiem Katalogu magii Mnicha Rudolfa zabytku $z$ XIII $w$. w tł. [z łac.] E. Karwota, Wrocław 1991

Madej-Anderson A., Lutherans in Cracow - Contesting the Sacred Topography, w: Lutheran Churches in Early Modern Europe, ed. A. Spicer, Farnham-Burlington (VT) 2012, s. 377-402

Mikołajczyk M., Proces kryminalny w miastach Matopolski XVI-XVIII wieku, Katowice 2013

Noga Z., Urzędnicy miejscy Krakowa, cz. 2: 1500-1794, Kraków 2008 (Spisy urzędników miejskich z obszaru dawnej Rzeczypospolitej, Śląska i Pomorza Zachodniego, t. 3: Małopolska, z. 1: Kraków)

Nowakowska N., Church, State and Dynasty in Renaissance Poland. The Career of Cardinal Fryderyk Jagiellon (1468-1503), Aldershot-Burlington (VT) 2007 (Catholic Christendom, 1300-1700)

Nyholm Kallestrup L., Knowing Satan from God. Demonic Possession, Witchcraft, and the Lutheran Orthodox Church in Early Modern Denmark, „Magic, Ritual, and Witchcraft”, 6, 2011, s. 163-182. 
Pilaszek M., Procesy o czary $w$ Polsce $w$ wiekach XV-XVIII, Kraków 2008

Siewert F., Die Lübecker Rigafahrer-Compagnie im 16. und 17. Jahrhundert, Berlin 1896

Słowiński J., Rozwój pisma tacińskiego w Polsce XVI-XVIII wieku, Lublin 1992

Sójka J., Regulus Wojciech, PSB, 30, 1987, s. 749

Stadin K., Seventeenth Century Baltic Merchants, w: Baltic Towns and Their Inhabitants. Aspects on Early Modern Towns in the Baltic Area, red. K. Stadin, Huddinge 2003, s. 56-73

Tazbir J., Procesy o czary, OiRwP, 23, 1978, s. 151-177

Wachholz L., O szpitalach innowierców w Krakowie. Szkic historyczny, „Archiwum Historii i Filozofii Medycyny", 2, 1925, s. 169-176

Wijaczka J., Handel zagraniczny Krakowa w potowie XVII wieku, Kraków 2002

Wijaczka J., Luteranie w Koronie od 1517 do 1795 r., w: Kościoty luterańskie na ziemiach polskich (XVI-XX w.), t. 1: W czasach Rzeczypospolitej Obojga Narodów, red. J. Kłaczkow, Toruń 2012, s. 13-88

Wijaczka J., Magia i czary. Polowanie na czarownice i czarowników w Prusach Ksiażęcych w czasach wczesnonowożytnych, Toruń 2008

Wijaczka J., Procesy o czary w Prusach Ksiażęcych (Brandenburskich) w XVI-XVIII wieku, Torun 2007

Wijaczka J., rec.: M. Pilaszek, Procesy o czary $w$ Polsce $w$ wiekach XV-XVIII, Kraków 2008, „Kwartalnik Historyczny”, 116, 2009, s. 113-126

Wyczański A., Uwarstwienie spoteczne w Polsce XVI wieku. Studia, Wrocław 1977

Wyporska W., Witchcraft in Early Modern Poland, 1500-1800, Basingstoke-New York 2013

Zygner L., Kobieta-czarownica w świetle ksiag konsystorskich z XV i poczattku $X V I w$., w: Kobieta i rodzina $w$ średniowieczu i na progu czasów nowożytnych, red. Z. H. Nowak, A. Radzimiński, Toruń 1998, s. 91-101

\section{German Merchants and a Witch in Cracow in 1642}

Witchcraft beliefs were widespread in late medieval and early modern Cracow. Like elsewhere, the confidence in the effectiveness of magic was shared by people of various ethnic and religious denominations. The source edition that supplements this article is a testimony the Cracow merchant Adam Fister gave at the local justice at the behest of John Minen, a Danzig patrician, on 25 October 1642. Fister confirmed the account of the Cracovians: John Brauer, Mathew Erfort, Peter Rotenstein, and of the Viennese merchant Daniel Frans, that Casper Bekman, a merchant of Lübeck had taken personal effects from Erfort that belonged to the Danzig tradesman. Then Bekman 
was putting a spell on Minen with the help of a hag whom he visited at the Spital Garden behind the city walls, near St Florian's Gate. Bekman intended to make Minen return to Cracow. Brauer, who was a witness to those practices, implored Bekman to give up magic because it was an offence to God. He was successful in his persuasion.

The discussed source excerpt bears notice for several reasons. The witch demanded a relatively high fee of 200 florins, which shows a firm trust in her abilities. Deep into the eighteenth century, the Spital Garden was also known as the Lutheran Garden. Graves that were discovered there in 1837 were identified as Arian, that is of the local followers of Socinianism, although there were no grounds for such an interpretation. Thus, the nineteenth-century tradition of Arian Square, whose continuation today is Arian Street, is unjustified. In light of the discussed report, there is no doubt that the graves were part of the Cracow Lutherans' cemetery, and, as often in such cases, the congregation had their spital, that is an almshouse, there. The Cracow merchants that are listed in the source must have belonged to the local Lutheran parish. Its members, we know next to nothing about, from 1636 met for services at the Calvinists' chapel near Cracow. Fister mentioned Suzanne Mayerhöfer, the wife of an elder of the Reformed congregation, as one of the women who had seen Bekman and his German companion at the spital.

Prof. dr hab. Waldemar Kowalski - wykładowca w Instytucie Historii Uniwersytetu Jana Kochanowskiego w Kielcach. Jego zainteresowania badawcze obejmują stosunki wyznaniowe, etniczne i dzieje Kościoła katolickiego w Polsce XV-XVIII w., emigrację z Wysp Brytyjskich do Europy Środkowej w XVI-XVII w., nauki pomocnicze historii, a szczególnie historię archiwów i kancelarii oraz epigrafikę.

Waldemar Kowalski - professor at the Department of History of the Jan Kochanowski University in Kielce. His scholarly interests include: religious and ethnic relations, the history of the Catholic Church in Poland in the $15^{\text {th }}-18^{\text {th }}$ centuries, emigration from the British Islands to Central Europe in the $16^{\text {th }}-17^{\text {th }}$ centuries, and the auxiliary disciplines of history, especially the history of archives and chancelleries as well as epigraphy.

E-mail: waldemar.kowalski@ujk.edu.pl 